\title{
HOT POTATOES ACTIVITIES TO IMPROVE GRAMMATICAL ACCURACY ACROSS DIFFERENT PROFICIENCY COURSES
}

\author{
IZASKUn VILLARREAL \\ Universidad Pública de Navarra \\ izaskun.villarreal@unavarra.es \\ Esther Gómez Lacabex \\ Universidad del País Vasco/Euskal Herriko Unibertsitatea (UPV/EHU) \\ esther.glacabex@ehu.es \\ Francisco Gallardo del Puerto \\ Universidad de Cantabria \\ francisco.gallardo@unican.es \\ María Martínez AdRIÁN \\ Universidad del País Vasco/Euskal Herriko Unibertsitatea (UPV/EHU) \\ maria.martineza@ehu.es \\ M. JunCAL GutiÉRREZ-MANGADO \\ Universidad del País Vasco/Euskal Herriko Unibertsitatea (UPV/EHU) \\ junkal.gutierrez@ehu.es
}

\begin{abstract}
Few studies have gauged the effects of Computer Assisted Language Learning -CALL- on the verbal accuracy of students. The current study explores the use of Hot Potatoes JCloze-type exercises as supplementary classroom work to enhance the English tense accuracy of university students enrolled in three EFL proficiency level courses -bigh-intermediate (B2) and advanced (C1 and C2). Tense marking was measured before and after a period of autonomous, self-paced CALL work in which students could access theoretical information and practiced with Hot Potatoes exercises. The comparisons revealed that the experience was mainly beneficial for the C1 level course group, the other two experimenting non-significant gains. Results only partially support a boosting effect of CALL additional practice. They also suggest that proficiency should be taken into consideration as it can affect the effect of treatment as not all
\end{abstract}


the proficiency level courses experienced advantages. Alternatives to improve effectiveness are then suggested.

Keywords: CALL, tenses, proficiency, grammar, technology, EFL.

\title{
HOT POTATOES PARA LA MEJORA DE LOS TIEMPOS VERBALES EN CURSOS DE DISTINTOS NIVELES LINGÜÍSTICOS
}

\begin{abstract}
RESUMEN. Este estudio explora el efecto de realizar ejercicios en Hot Potatoes sobre la utilización de los tiempos verbales de tres grupos de diferente nivel de inglés como Lengua Extranjera, ILE, - B2 (intermedio alto), C1 y C2. Para ello, se midió la utilización de los tiempos verbales antes y después del tratamiento. Este consistió en completar ejercicios en Hot Potatoes y acceder a explicaciones teóricas sobre los usos y funciones de los tiempos verbales. Los resultados indicaron que la intervención solo fue beneficiosa para el grupo de C1, ya que los otros dos grupos no experimentaron mejoras significativas. Los resultados, por lo tanto, solo sustentan parcialmente los beneficios del Aprendizaje de Lenguas Asistido por Ordenador (ALAO) para la mejora de la gramática y remarcan la importancia de considerar el nivel de competencia lingüística al diseñar experiencias ALAO. Finalmente, se sugiere que, para aumentar su incidencia, estas prácticas deberían ser más personalizadas y dinámicas y estar mejor integradas.
\end{abstract}

Palabras clave: ILE, ALAO, gramática, proficiencia, tiempos verbales, nivel.

Received 11 February 2019

Revised version accepted 24 July 2019

\section{INTRODUCTION}

Acquiring a proficient language competence is necessary for students enrolled in English Studies-oriented Degrees. However, it is often the case that the content stipulated in the curriculum and the practice implemented by the teachers is not sufficient for all students to reach the desired standards. In particular, inaccurate use of certain aspects of language, such as verb tense, aspect and agreement has been reported to be pervasive (Hinkel 2004; Ayoun and Salaberry 2008; García Mayo and Villarreal 2011; Villareal 2011; Garrido and Rosado 2012).

Many studies have underscored the merits of Computer Assisted Language Learning -CALL- for language learning as it seems to foster flexibility (Macedo-Rouet, Ney, Charles, and Lallich-Boidin 2009), student motivation (Bueno-Alastuey and López Pérez 2014), participation (Hung 2015), as well as learner autonomy (Gimeno-Sanz 2009). Availability, amount of individual practice and the student's level of control over the treatment have been deemed the reasons for the success of CALL practices (Penning 
deVries, Cucchiarini, Bodnar, Strik and van Hout 2015). Despite these benefits, few studies have specifically addressed the effect of CALL on grammar development (Sagarra and Zapata 2008; Penning de Vries et al. 2015; Swain and Swain 2017), and of verb tense in particular (Salaberry 2000; Izquierdo 2014; Alimah 2015; Stelea and GirónGarcía 2017). One possible reason might be that current teaching approaches focus on the communicative goals of language (Council of Europe 2001), and negative perceptions regarding drill practice are associated with traditional and outdated language teaching approaches. Consequently, CALL initiatives have been aimed mainly at skill development and the rationalization and promotion of skill-based activities (Kawauchi 2005; Blake 2016), neglecting repetitive drill practice which, nevertheless, contributes to the automatization of language forms (DeKeyser 2007, 2010).

Likewise, a number of CALL studies have looked into several factors that mediate CALL effectiveness. But although the type of Information and Communication Technology (ICT), the type of task, the feedback provided or the skill or language area targeted (Ayoun 2001; Sagarra and Zapata 2008; Penning de Vries et al. 2015; Blake 2016) have attracted attention, little is known about whether students' proficiency mediates CALL effectiveness (Kawauchi 2005; De la Cruz Villegas and Izquierdo 2014; Izquierdo 2014; Swain and Swain 2017).

One of the areas in which even advanced L2 groups -CEFR B2, C1 and C2 levels-, who are communicatively competent users, have been reported to experience difficulties is grammatical competence. The heavy workloads of teachers, however, make "it impossible for a teacher to tailor grammatical exercises to the needs of each individual learner" (Penning de Vries et al. 2015: 550), even more with the large number of students included in standard university groups. Providing opportunities for extensive practice seems, thus, important. In addition, few studies have looked at whether learners at different proficiency levels benefit equally from using CALL when learning the same grammatical points (Kawauchi 2005; De la Cruz Villegas and Izquierdo 2014; Izquierdo 2014; Izquierdo et al. 2015; Swain and Swain 2017) The current study aims to contribute to this line of research by investigating whether CALL fosters increased tense accuracy among students attending varying EFL proficiency level courses at university. The students were invited to practice English verb tenses autonomously with Hot Potatoes fill-in the gap-related exercises, on-line grammar explanations and pronunciation guidelines.

\section{LITERATURE REVIEW}

\subsection{CALL AND LANGUAGE LEARNING}

With the advent of technology, technological resources have been included in many different ways in language courses (Gallardo del Puerto and Gamboa 2009) 
and have been reported to offer a myriad of possibilities to teachers and students. Including ICT in language courses has been reported to help students take ownership of their own learning (Brown 2002), to increase exposure to language and promote autonomy, to boost students' motivation to engage with learning, to improve the classroom atmosphere, to provide immediate feedback and to relieve teachers' workload (Sagarra and Zapata 2008; Bueno-Alastuey 2009; Erben, Ban and Castañeda 2009; Bueno-Alastuey and López-Pérez 2014; Soleimani and Raeesi 2015). In addition, two meta-analyses that have been conducted to gauge the effectiveness of CALL for language learning (Zhao 2003; Grgurovic, Chapelle and Shelley 2013) have concluded that FL instruction supported by technology is at least as effective as instruction without technology, and in rigorous case design studies, CALL groups have been reported to be better than non-CALL groups (Grgurovic et al. 2013). Most importantly, Grgurovic et al. (2013) concluded in their meta-analysis that among the studies with a pre-post experimental design, learners that were supported by CALL improved from the pre-test to the post-test when they used a CALL program as an add-on (that is, additionally to instruction in a traditional language course). Their study also reported that learners improved regardless of the treatment length, their native language, the size of the sample or the setting of the study. The authors, however, could not clearly establish how CALL efficiency was mediated by language proficiency as only one study involving advanced participants had been included in the meta-analysis. The present study will contribute to advance the knowledge in this respect, as a wider range of proficiency level courses will be included.

\subsection{CALL AND THE TEACHING OF GRAMMAR}

Although the potential of technology to improve language skills has been widely defended (see Blake 2016 for a recent summary), studies which have focused on the effects of technology on specific areas of language are still lacking (Bueno-Alastuey and López Pérez 2014). The current view on language learning and teaching by which communicative language competence is promoted has emphasized research on skills development while pushing investigations on the teaching and learning of specific language areas into the background (but see e.g. Nutta 1998; Salaberry 2000; Torlakovic and Deugo 2004; Kiliçkaya 2015).

However, linguistic competence is a basic component of communicative language competence and, among others, it comprises grammatical competence described as "the knowledge of, and ability to use, the grammatical resources of a language" as stated in the CEFR (Council of Europe 2001: 112). Hence, scaled descriptors for grammatical accuracy knowledge and abilities have been developed 
for language learning and teaching (2001: 114) and consistent grammatical control of complex language is expected at advanced levels of proficiency. Mastery of grammatical aspects is, therefore, included within communicative language competence and thus, neglecting it might hinder speakers' opportunities to progress towards higher accuracy levels.

Grammar teaching through CALL has been the focus of some studies which have yielded mixed results, some advocating for its positive impact (Nutta 1998; Salaberry 2000; Torlakovic and Deugo 2004; Sagarra and Zapata 2008; Kiliçkaya 2015), while some others have obtained comparable or even worse results when compared to face-to-face instruction (Swain and Swain 2017).

Different grammatical aspects like phrasal verbs (Mohammadi and Mirdehghan 2014), articles, tenses and plurals (Al-Jarf 2005), the passive voice (Abu Naba'h et al. 2009; Abu Naba'h 2012), past simple and present perfect tenses (Stelea and Girón-García 2017) or overall grammar (Sagarra and Zapata 2008) have been shown to be favored by CALL practice. These studies have shown that the aspects contributing to the CALL advantage are that CALL: i) helps students consolidate class content, ii) caters for individual differences, iii) raises motivation, iv) increases opportunities for grammar practice, v) allows for multiple attempts vi) provides immediate feedback, and vii) respects students' own working pace.

Attempts have also been made to determine which factors mediate CALL instruction effectiveness including its (a)synchronous nature (Salaberry 2000; Abrams 2003), its input or output-focus (Nagata 1998a, 1998b), the task (Hampel 2006; Blake 2016), presence or absence of feedback (Ayoun 2001), the target grammatical aspect (Nagata 1998a, 1998b; Salaberry 2000; Torlakovic and Deugo 2004; Martínez Pardo 2014) or the effect of textual-enhancement (Doughty 1991). Some studies have also underscored the need of CALL research to explore the impact of learner profiles on L2 learner results (Kawauchi 2005; De la Cruz Villegas and Izquierdo 2014; Izquierdo 2014; Izquierdo et al. 2015; Swain and Swain 2017). However, the impact of different proficiency levels has been scarcely looked into (Izquierdo 2014; Swain and Swain 2017).

In one of the few studies contrasting multiple proficiency students, Swain and Swain (2017) compared first year beginner and second year beginner learners of Spanish in blended and face-to-face instruction programs with varying experience in ICT. The technology-enhanced content was related to classroom content (Sagarra and Zapata 2008) and included level appropriate vocabulary and grammar exercises accessible through an integrated learning platform. Students were required to complete the assignments before attending the following class. Course scores and final vocabulary, grammar, language comprehension and oral 
proficiency tests were compared. When the results from the two proficiency groups were aggregated, face-to-face groups outstripped the technology-enhanced groups in both metrics. When proficiency differences were examined, face-to-face groups obtained higher overall scores across proficiencies, but unlike the first year beginner group, the second year one improved more than the face-to-face group. They concluded that the difference was related to experience with ICT and underscored the importance of extended ICT use before advantages associated with blended learning can be observed (Sagarra and Zapata 2008) and highlight the need for ICT literacy to minimize side effects.

Izquierdo (2014) examined multimedia effects on the development of French past forms. Learners who were at early and late stages of past-tense development were contrasted after having received four weeks of multimedia instruction in class. Learners were tested before, immediately after and three weeks after the experiment was over. The results revealed that only those at the initial stages improved past-tense provision. The author concludes by emphasizing the need to consider multimedia instruction design variations as learners' L2 grammar evolves.

All in all, among the two studies targeting the effect of proficiency, just one has included late/advanced stages of development. The investigation of upperintermediate and advanced learners seems to be mandatory as higher level students still show pervasive difficulties with tense accuracy also common among other advanced learners (Hinkel 2004; Collins 2007; Garrido and Rosado 2012). Our study will fill this gap by examining students enrolled in an English Studiesoriented degree (in B2 to C2 courses).

\subsection{TENSE IN FOREIGN LANGUAGE ACQUISITION}

Tense is one of the six devices used to encode time in natural languages and is realized through inflectional morphology in the verb, frequently, in combination with an auxiliary (Klein 2008). As different languages employ different (combinations of) devices to express time, difficulties in marking time among L2 or FL learners are abundant (Bardovi-Harlig 2000). In fact, a lack of consistency when producing target verbal endings is a characteristic of most L2 or FL learners regardless of their mother tongue (L1), the language they intend to learn and their proficiency level in the target language (Hinkel 2004; Ayoun and Salaberry 2008; Garrido and Rosado 2012; Villarreal 2011). These difficulties have often been attributed to an unstable FL system (Ayoun and Salaberry 2008), to mapping problems (DeKeyser 2007; Villarreal 2011; Garrido and Rosado 2012; Gutiérrez-Mangado and Martínez Adrián 2018) or to usage difficulties (Hinkel 2004). To overcome those difficulties, some authors have proposed systematic 
practice and repetition to extend the range of accessible grammatical structures, to raise grammatical awareness and to automatize knowledge (Hinkel 2004; DeKeyser 2010; Garrido and Rosado 2012).

As a particularly error-prone area, tense marking usage could improve with intensive pedagogical intervention and practice (García Mayo 2008; Villarreal 2011; DeKeyser and Criado 2013; Martínez Adrián and Gutiérrez-Mangado 2015; Gutiérrez-Mangado and Martínez Adrián 2018). ICT (i.e. Hot Potatoes) used as an add-on or a complement to classroom face-to-face teaching could provide extended practice on English tense marking (Hinkel 2004; Collins 2007; Garrido and Rosado 2012).

\subsection{HOT POTATOES AND GRAMMAR LEARNING}

Hot Potatoes (https://hotpot.uvic.ca/) is an authoring tool that allows the creation of online exercises specifically suited for a given language topic, often grammar. Hot Potatoes is popular (there are over 150000 registered users) because it is a free resource for educational institutions, it can be used to teach any subject, it is rather intuitive and easy to use, it offers different exercise types, it can be integrated in institutional language learning platforms like Moodle, it provides feedback and scoring, and it allows for the upgrading and editing of already created materials. Although currently Hot Potatoes is no longer supported technically, it is still widely used among language teachers (Gimeno-Sanz 2016).

Research has signaled that the effectiveness of technological resources such as Hot Potatoes might be compromised by the language aspect being investigated (see Nagata 1998a, 1998b; Salaberry 2000; Martínez Pardo 2014; for earlier accounts using different CALL tools) and by the integration of the learning activities into the broader teaching method (Sagarra and Zapata 2008; Soleimani and Raeesi 2015). Nevertheless, there is a paucity of research exploring the benefits of Hot Potatoes to teach grammar and the few studies that exist are based on similar samples of intermediate secondary learners learning present tense by using different exercise types provided in Hot Potatoes Quiz and JCloze. Arumsari (2014) measured whether teaching present simple through Quiz favoured simple tense provision ( $n=33$ ). The pre-post comparison yielded positive results and he concluded that Hot Potatoes helped in the learning of present simple tense. The results by Alimah (2015) are parallel and similarly positive results were reported for the learning of the present tense by using JCloze $(n=44)$. Both studies showed that Hot Potatoes can improve students' grammar usage and encouraged using it for the teaching of grammar. 
In order to contribute to the ongoing efforts to identify the effects of CALL on grammatical tense accuracy, the present study investigates the potential effects of complementary tense practice in terms of accuracy scores across three English proficiency level courses: B2, C1 and C2. The following two questions are addressed:

1. Do the three English proficiency level courses improve from the pre-test to the post-test regarding tense accuracy after the CALL treatment they were engaged in?

2. Do the various proficiency level courses benefit equally or differently from the training?

\section{METHODOLOGY}

\subsection{PARTICIPANTS}

This study was part of a larger project that was carried out at a university in Northern Spain. It aimed at reinforcing the command of verb tenses in three EFL groups through the use of CALL.

Participants were Basque-Spanish bilingual students (49 females and 14 males) ranging in age from 17 to 30 in their 1st, 2nd and 3rd year of the BA in English Studies. These students must have passed the English university entrance exam, which guarantees a B1 CEFR level in reading and writing skills in English. At the moment of testing, the first year students were receiving English lessons (English Language I) in a skill-oriented language course which designed practice and assessment towards B2 CEFR level provision with added practice on grammar and vocabulary. The second year learners were taking 'English Language III' (C1 CEFR level), while the third year students were doing 'English Language V' (C2 CEFR level). The participants were grouped according to the language class they were taking at the time of data collection. In other words, the participants in the targeted CEFR level B2 were all taking English I, those targeting CEFR level C1 were taking English III and those targeting CEFR level C2 were taking English V. All the students in each class participated in the study and participation was voluntary. However, only those participants who actually completed all the tasks were included in the final analysis. From the 130 participants who participated in the study, only 63 completed all the tasks part of the study, which are described below. That is why the number of participants in each group varies. Table 1 shows the characteristics of the participants. 
Table 1. Details of participants: number of participants in each group, age range, gender, English subject and year course taken and CEFR level.

\begin{tabular}{|c|c|c|c|c|c|c|}
\hline Group & $\mathbf{N}$ & Age range & $\begin{array}{c}\text { Gender } \\
\text { Male female }\end{array}$ & Year & Subject & $\begin{array}{l}\text { Targeted } \\
\text { CEFR level }\end{array}$ \\
\hline B2 & 17 & $17-23$ & $3 \quad 14$ & $1^{\text {st }}$ & English Language I & B2 \\
\hline $\mathrm{C} 1$ & 27 & $18-30$ & $8 \quad 19$ & $2^{\text {nd }}$ & English Language III & $\mathrm{C} 1$ \\
\hline $\mathrm{C} 2$ & 19 & $19-24$ & 316 & $3^{\text {rd }}$ & English Language V & $\mathrm{C} 2$ \\
\hline
\end{tabular}

\subsection{INSTRUMENTS}

The project was conducted following a pre-test/post-test design during OctoberDecember, 2013. Students were asked to read specific tutorials on the use of verb tenses (see Appendices 1A and 1B) before completing different on-line tasks as homework on a weekly basis (see Appendices 2A and 2B). Both the tutorials and the activities were created by the members of the project.

All the items were revised by a native speaker who verified that the sentences provided enough information for the identification of the verb tenses included (present, past and future as well as simple, perfect and continuous forms) and, hence, for the gap to be filled. Additionally, the battery of correct answers considered various possible answers for each gap. A total of 17 sets of written exercises with 36 gaps to be filled amounting to a total of 612 sentences with a gap were designed for each language level.

The instrument used as pre-test and post-test provided initial and final data for this study. A total number of 110 tense gaps were presented in 48 items in sentence frame and short paragraph frame, which the students had to fill in with a suitable verb tense (see Appendix 3).

The same written test was administered as pre-test and post-test for all proficiency groups. It was completed during class time in the same room in which students received regular instruction.

\subsection{PROCEDURE}

The pre-tests were administered at the beginning of October, while the platform activities were available throughout mid-October to end-November. The post-tests were collected in December. The weekly exercises which made up the treatment were delivered in Hot Potatoes JCloze format in the on-line learning platform offered by the institution (Moodle), which the instructors of the respective language courses used. Students were invited to complete the activities proposed 
in the platform as outside-class supportive additional practice to the tense contents covered in class. The verb tenses added to each level were representative of the tense forms included in each language course programmes.

\subsection{DATA ANALYSIS}

Scores were coded in SPSS.15 and computed as percentage correct. The variables exhibited normal distribution and hence parametric tests were applied with a 95\% confidence interval. T-tests were performed to contrast the pretests and post-tests results across the courses. To identify differences between proficiency level courses at the pre and post-tests, one-way ANOVAs were run. Finally, normalized gain scores were calculated to establish differentiated course gains.

\section{RESULTS}

So as to ascertain the effects of the CALL treatment, we first performed T-tests between pre and post-test for the average scores of all the groups (Grand Mean): It indicated that there were significant differences between the two testing phases when all the groups were taken into consideration $(\mathrm{t}=-3.64, \mathrm{p}=.001)$. As can be seen in table 2, post-test scores were higher than pre-test scores, indicating that the students were able to provide more accurate tenses after the CALL treatment.

Table 2. Pre-test and post-test correct \%, standard deviations (SD) and Normalized Gain values for B2, C1 and C2 proficiency level courses.

\begin{tabular}{|l|c|c|c|c|c|c|}
\hline Course level & $\begin{array}{c}\text { Pre-test } \\
\mathbf{\%}\end{array}$ & $\mathbf{( S D )}$ & $\begin{array}{c}\text { Post-test } \\
\mathbf{\%}\end{array}$ & $\mathbf{( S D )}$ & $\begin{array}{c}\text { Normalized } \\
\text { Gain }\end{array}$ & (SD) \\
\hline Grand mean & 61.28 & 11.75 & 65.67 & 12.67 & 1.00 & .00 \\
\hline B2 & 55.25 & 11.56 & 58.51 & 8.16 & 0.31 & .24 \\
\hline C1 & 68.11 & 8.65 & 75.12 & 10.25 & 0.22 & .23 \\
\hline C2 & 56.51 & 10.85 & 58.36 & 10.51 & 0.17 & .25 \\
\hline
\end{tabular}

Further T- tests for each experimental group revealed significant differences between pre-test and post-test for the $\mathrm{C} 1$ proficiency level course $(\mathrm{t}(24)=-5.3, \mathrm{p}=$ .000) only. No significant differences between times were found for the B2 course $(\mathrm{p}>.05)$ or $\mathrm{C} 2$ level course $(\mathrm{p}>.05)$. Although all level courses experimented some improvement in tense provision in the post-tests, results indicated that such improvement was only significant for the C1 level course. 
A one-way ANOVA test with course level (B2, C1 and C2) as a betweensubjects factor revealed that there were significant differences between courses for pre-test $(\mathrm{F}(2,53)=10.21, \mathrm{p}=.000)$ and post-test $(\mathrm{F}(2,53)=10.21, \mathrm{p}=.000)$, as might be expected, given their different proficiency levels. However, post-hoc pairwise Bonferroni analyses applied to the pre-test indicated significant differences between the C1 course and B2 course $(p=.000)$ and between the C1 and C2 courses $(\mathrm{p}=.005)$ but not between the B2 and C2 courses $(\mathrm{p}>.05)$ indicating that the C1 level course scored significantly higher than the B2 and the C2 level courses as can be seen in figure 1 .

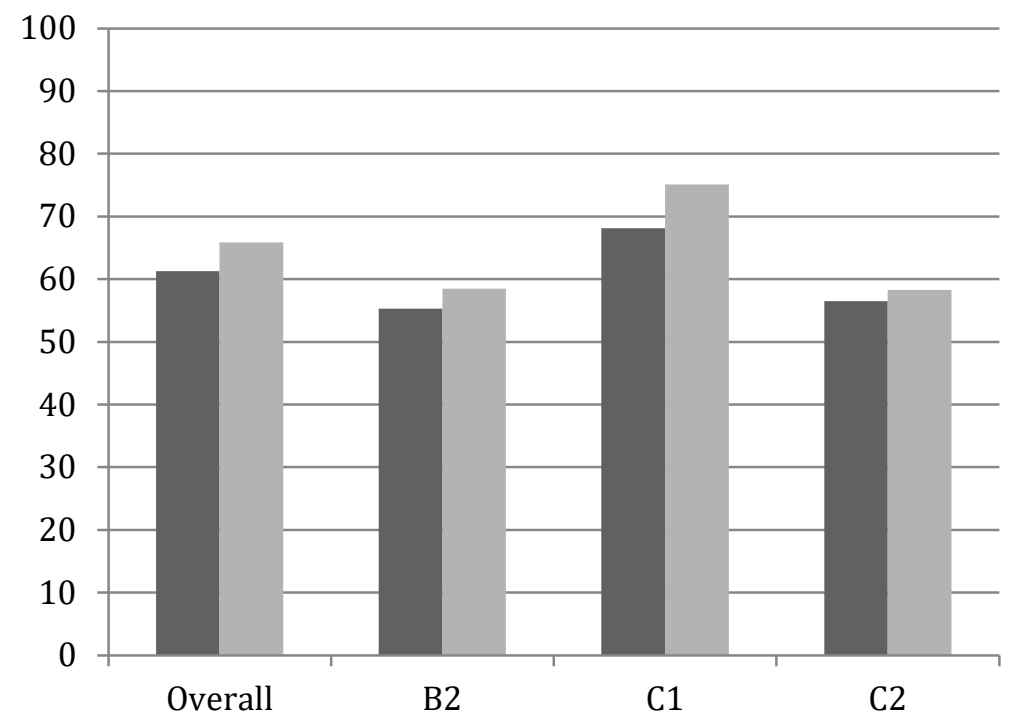

Figure 1. Correct $\%$ in pre-test and post-test for all the courses (overall) and for the B2 level course, C1 level course and C2 level course.

Differences between the courses in the post-test (one-way ANOVA) remained within the same trend observed in the pre-test phase. They were significant between the B2 and C1 courses $(\mathrm{p}=.000)$, and between the C1 and C2 courses $(\mathrm{p}=.000)$, but not between the B2 and C2 level courses $(\mathrm{p}>.05)$.

As the groups exhibited varying onset levels, normalized gain scores were calculated and statistically compared with one-way ANOVA and pair-wise Bonferroni comparisons. The tests confirmed that there was a course level effect $(\mathrm{F}(2,57)$ $=4.54, \mathrm{p}=.015)$, that is, that courses underwent gains differently. Post-hoc comparisons between level courses revealed near-significant differences between 
the C1 and C2 level course $(\mathrm{p}=.051)$ and significant differences between the $\mathrm{C} 1$ and B2 courses $(\mathrm{p}=.045)$, suggesting, once more, that the gain experienced by the C1 level course was significantly higher than the gain experienced by the other two courses.

\section{DISCUSSION}

The main objective of the present paper was to explore the effects of a CALL treatment across three proficiency level courses belonging to a BA in English Studies. They were exposed to extra English verb tense practice and revision outside class on the institution on-line platform. Their pre- and post-performance on a fill-in-the-gap written task was analysed to explore possible improvements.

The preliminary analysis of pre-test scores revealed that learners exhibited $61 \%$ of accuracy in their delivery of English verb tenses before the intervention. Given the proficiency level courses analysed, this finding suggests that, even at high levels of English proficiency, learners still exhibit difficulties in the use of verb tenses. Our results coincide with those of previous investigations which have attested that tense and aspect provision are problematic in L2 acquisition (Bardovi-Harlig 2000; Hinkel 2004; DeKeyser 2007, 2010; Ayoun and Salaberry 2008; García Mayo and Villarreal 2011; Villarreal 2011; Garrido and Rosado 2012).

As we interpreted the previous results as existing room for improvement, our first research question sought to ascertain the potential effect of computersupported additional practice within three tertiary language courses in an English Studies degree in Spain. We first explored overall differences between pre-test and post-test for all the groups. A higher post-test mean was found to significantly differ from the pre-test score, suggesting that the CALL treatment may have helped these learners in delivering more accurate verb tenses.

Our second aim in this study was to explore the effects the same treatment might have in different proficiency level courses. While the three proficiency groups showed gains, only one of them (C1 level course) presented significant differences between testing times. These results merit some comments. First, our design may be lacking statistical power to evince a more compelling result for the other groups, which only exhibited moderate gains. Second, in the case of the B2 level course, it might be that it did not maximally benefit from the affordances that the CALL treatment offered as the subtle form-meaning distinctions might still be challenging for them. DeKeyser and Criado (2013) have acknowledged the potential power of systematic practice for grammatical development, which in this context may come in the form of more contexts or more time. The C2 level course, 
however, presents a different profile. Despite the fact that the institutional system has granted this group of students a C2 English proficiency level (they have passed all the previous assessment requirements), the two tests administered under the present experimental design (pre-test and placement test) failed to acknowledge this proficiency level for these students regarding verb tense accuracy. The results for this group hint at two possible interpretations: on the one hand, results could be indicating that there may not necessarily be a direct relationship between general competence and verb tense accuracy (Martínez Adrián and Gutiérrez-Mangado 2015). In the case of this particular intact group, there may be more variability in tense use than in the C1 level course, which may have included individuals with better tense provision skills. On the other hand, it may be that, although granted a C2 level because of having passed C1 assessment requirements, they still do not hold such competence level and, hence, better performance may not necessarily be expected from them. This supports recommendations for extended exposure and practice of tense form-meaning mappings even at advanced stages of proficiency to ensure that verb tense functions are better acquired (Collins 2007; DeKeyser 2007, 2010).

In addition, the results indicated that not all forms of practice may work equally well for distinct proficiency level courses. Interestingly, our intra-group comparisons have disclosed uneven treatment effects. Thus, our findings partially support those which have concluded that CALL treatment can become an aid in language learning, more particularly for grammar (e.g. Nutta 1998; Salaberry 2000; Al-Jarf 2005; Sagarra and Zapata 2008; Kiliçkaya 2015; Penning de Vries et al. 2015) and verb tense learning (Abu-Naba'h et al. 2009; Abu-Naba'h 2012; Arumsari 2014; Izquierdo 2014; Alimah 2015; Stelea and Girón-García 2017). The distinct effect observed as regards different proficiency level students seems to compromise its usefulness and it suggests that maybe CALL treatments would require certain characteristics so as to be more advantageous. As Izquierdo (2014) suggests, design variations may need to be considered as learners' L2 grammar evolves. It seems that although learners might struggle with similar forms, the practice and scaffolding teachers provide them with to overcome such difficulties should be tailored to their proficiency levels and thus, differentiated learning activities might be needed. Several suggestions can be put forward. First, not all groups may benefit from mechanical repetitious tasks and may need more communication-oriented tasks to establish the form-meaning relationships in the long-term memory (DeKeyser and Criado 2013).

An additional feature that could have undermined the effectiveness of the treatment could be related to the fact that although the contents and tasks were complementary to classroom materials and tasks and that the instructors did remind 
learners about the possibility of reporting doubts, there were very few interactions between the instructors and the students regarding the CALL activities. This lack of integration might have affected the success of the treatment as participating in integrated CALL courses can shape attitudes toward CALL tools (Sagarra and Zapata 2008; Bueno-Alastuey and López Pérez 2014).

Furthermore, another issue in the current study is that various tense forms were targeted and some of them might be harder to acquire than others as they might lack saliency and be more difficult to attain (DeKeyser 2007, 2010). The studies that have used Hot Potatoes or other CALL initiatives for discrete grammar points like present tense learning, passives or nominal modifiers (Nagata 1998a, 1998b; Abu Naba'h 2012; Arumsari 2014; Alimah 2015) have identified positive results. The current study, however, was not designed to explore whether the CALL intervention affected tense forms differently, and thus how CALL affects the distinct tense forms and how these are mediated by proficiency cannot be established.

Uses of dynamic exercise systems (as in Galloway and Peterson-Bidoshi 2008) or of what is referred to as intelligent computer assisted language learning or iCALL were also lacking from our pedagogic intervention. iCALL integrates natural language processing and artificial intelligence knowledge into CALL to design learning programs "that come closer to natural language interaction between humans than has been the case in traditional CALL" (Heift 2010: 443). iCALL goes beyond simple notification of an error and provides deeper analysis of learners' input and individualization of the learning process, which yield immediate benefits for teachers and students. iCALL would have provided a more meaningful interaction and learning context by incorporating personalized learning itineraries for example, and, as a result, more differentiated, tailored instruction. Further improvement could also come from the combination of the current intervention with a more collaborative one using other types of ICT tools such as Google Docs or wikis which would promote collaborative language learning (see Storch 2013 for an overview of computer mediated collaboration).

Albeit the limitations identified, our findings raise pedagogical implications for the design of CALL grammar interventions. Students' proficiency should be considered when making decisions about the type of practice needed to help students improve their grammar use. Proficiency seems to mediate CALL grammar learning and different instructional designs may be considered to support L2 grammatical development (Izquierdo 2014; Izquierdo et al. 2015). Despite common tense difficulties, it seems that the practice designed should be assorted, integrated, dynamic and tailored to student proficiency levels. 
Further research should also concentrate on the investigation of more profitable uses of CALL where tense practice hinges on meaningful tasks, that is, on tasks that are more engaging and less systematic, in combination with interactive and collaborative practices where learners are able to pool their knowledge together and progress further (Storch 2013).

\section{CONCLUSION}

This study set out to investigate whether CALL tense practice with JCloze type Hot Potatoes activities boosted English verb tense provision among B2, C1 and C2 tertiary students, and whether differences in the treatment effect could be found between them. We only found significant improvements for the C1 level course. The other two courses experienced improvements which were not statistically significant. Our findings suggest that tense marking may be permeable to CALL treatments and partially support studies pointing towards the potential positive effects of autonomous supplementary CALL practice on tense marking (Al-Jarf 2005; Abu-Naba'h et al. 2009; Abu-Naba'h 2012; Alimah 2015). We suggest that further improvements might be achieved if the treatment proposed was combined with supplementary Hot Potatoes activities designed to be more interactively dynamic and better integrated in the language course. Our findings also suggest that competence may cut across the effects of treatment and highlights the importance of varying the design of teaching materials and practice to meet distinct proficiency needs.

\section{ACKNOWLEDGEMENTS}

We thank language lecturer Inés Uribe-Echeberria for her active collaboration in materials development. We are also very grateful for the support provided by Dr. Camino Bueno-Alastuey in steering the focus of this work. Finally, we would like to acknowledge the Language and Speech Laboratory group, LASLAB, from the University of the Basque Country and the first author would also like to acknowledge the institute for Advanced Social Research I-Communitas from the Public University of Navarra.

\section{FUNDING}

The present study was supported by the 6550/2012-14 Education Innovation Project: from the University of the Basque Country (UPV/EHU). 


\section{REFERENCES}

Abrams, Z. I. 2003. "The effect of synchronous and asynchronous CMC on oral performance in German”. The Modern Language Journal 87 (2): 157-167.

Abu Naba'h, A. 2012. "The impact of computer assisted grammar teaching on EFL pupils' performance in Jordan”. International Journal of Education and Development using Information and Communication Technology (IJEDICT) 8 (1): 71-90.

Abu Naba'h, A., Hussain, J., Al-Omari, A. and S. Shdeifat. 2009. "The effect of computer assisted language learning in teaching English grammar on the achievement of secondary students in Jordan". The International Arab Journal of Information Technology 6 (4): 431-439.

Alimah, P. M. 2015. The Effectiveness of Using "Hot Potatoes" to Teach Students "simple present tense" at SMPN 1 Ngutut Tulungagung. Unpublished PhD thesis. State Islamic Institute of Tulungagung: Tulungagung. $<$ http://repo.iaintulungagung.ac.id/1863/>.

Al-Jarf, R. S. 2005. "The effects of online grammar instruction on low proficiency EFL college students' achievement”. The Asian EFL Journal 7 (4): 166-190.

Arumsari, A. 2014. The Effectiveness of Using Hot Potatoes Quiz towards Students' Grammar Achievement in Simple Present Tense at the Seventh Grade of MTs Al-Huda Bandung Tulungagung. Tulungagung. Unpublished $\mathrm{PhD}$ thesis. State Islamic Institute (IAIN) of Tulungagung: Tulungagung. <http://repo.iaintulungagung.ac.id/146/>

Ayoun, D. 2001. "The role of negative and positive feedback in the second language acquisition of the passe' compose' and imparfait". The Modern Language Journal 85 (2): 226-243. http://doi.org/10.1111/0026-7902.00106.

Ayoun, D. and M. R. Salaberry. 2008. "Acquisition of English Tense-Aspect Morphology by Advanced French Instructed Learners". Language Learning 58 (3): 555-595.

Bardovi-Harlig, K. 2000. Tense and Aspect in Second Language Acquisition: Form, Meaning, and Use. Malden, MA: Blackwell.

Blake, R. 2016. "Technology and the four skills". Language Learning \& Technology 20 (2): 129-142. <http://llt.msu.edu/issues/june2016/blake.pdf>.

Brown, H. 2002. Strategies for Success: A practical Guide to Learning English. New York, NY: Addison Wesley Longman Inc.

Bueno- Alastuey, M. C. 2009. "Using WebCT in a course of English for Academic/ specific purposes: The case of English for agriculture". Teaching Academic and Professional English Online. Eds. I. Gonzalez-Pueyo, C. Foz, M. Jaime and M. J. Luzon. Bern, Switzerland: Peter Lang. 127-152. 
Bueno-Alastuey, M. C. and M. V. López Pérez. 2014. "Evaluation of a blended learning language course: students' perceptions of appropriateness for the development of skills and language areas". Computer Assisted Language Learning 27 (6): 509-527. http//doi.org/10.1080/09588221.2013.770037.

Collins, L. 2007. "L1 differences and L2 similarities: teaching verb tenses in English". English Language Teaching Journal 61 (4): 295-303.

Council of Europe. 2001. Common European Framework of Reference for Languages: Learning, Teaching, Assessment. Cambridge, UK: Cambridge University Press. $<$ http://www.coe.int/t/dg4/linguistic/source/Framework_EN.pdf>.

DeKeyser, R. M. 2007. Practice in a Second Language: Perspectives from Applied Linguistics and Cognitive Psychology. Cambridge, England: Cambridge University Press.

DeKeyser, R. M. 2010. "Practice for second language learning: Don't throw out the baby with the bathwater". International Journal of English Studies 10 (1): 155-165.

DeKeyser, R. M. and R. Criado. 2013. "Automatization, skill acquisition, and practice in second language acquisition". The Encyclopedia of Applied Linguistics. Ed. C. A. Chapelle. London, UK: Blackwell. 1-8.

De la Cruz Villegas, V. and J. Izquierdo. 2014. "Multimedia instruction on Latin roots of the English language and L2 vocabulary learning in higher education contexts: learner proficiency effects". Sinéctica Revista Electrónica de Educación 42: 1-11.

Erben, T., Ban, R. and M. Castañeda. 2009. Teaching English Language Learners through Technology. New York, NY: Routledge.

Gallardo del Puerto, F. and E. Gamboa. 2009. "The evaluation of computer-mediated technology by second language teachers: collaboration and interaction in CALL”. Educational Media International 46 (2): 137-152.

Galloway, D. and K. Peterson-Bidoshi. 2008. "The case for dynamic exercise systems in language learning". Computer Assisted Language Learning 21 (1): 1-8. https://doi.org/10.1080/09588220701865433.

García Mayo, M. P. 2008. A focus on form approach in language pedagogy: Findings from research in an EFL context. Estudios de Filología Inglesa: Homenaje a la Dra. Asunción Alba Pelayo. Eds. M. T. Gilabert Maceda and L. Alba Juez. Madrid, Spain: UNED. 141-161.

García Mayo, M. P. and I. Villarreal. 2011. "The development of suppletive and affixal tense and agreement morphemes in the L3 English of Basque-Spanish bilinguals". Second Language Research 27: 129-149.

Garrido, C. and C. Rosado. 2012. "Errors in the use of English tenses". Íkala, Revista de Lenguaje y Cultura 17 (3): 285-296. 
Gimeno-Sanz, A. 2009. Online course design and delivery: The Ingenio authoring system. Teaching Academic and Professional English online. Eds. I. GonzalezPueyo, C. Foz, M. Jaime, and M. J. Luzon. Bern: Peter Lang. 83-105.

Gimeno-Sanz, A. 2016. "Moving a step further from "integrative CALL". What's to come?". Computer Assisted Language Learning 29 (6): 1102-1115. http://doi.or g/10.1080/09588221.2015.1103271.

Grgurovic, M., Chapelle, C. A. and M. Shelley. 2013. "A meta-analysis of effectiveness studies on computer technology-supported language learning". ReCALL 25 (2): 165-198. http://doi.org/10.1017/S0958344013000013.

Gutiérrez-Mangado, M. J. and M. Martínez Adrián. 2018. "CLIL at the interfaces". Journal of Immersion and Content-Based Language Education (JICB) 6(1): 85-112.

Hampel, R. 2006. "Rethinking task design for the digital age: A framework for language teaching and learning in a synchronous online environment". ReCALL 18 (1): 105-121.

Heift, T. 2010. "Developing an Intelligent Language Tutor". CALICO Journal 27 (3): 443-459.

Hinkel, E. 2004. "Tense, aspect and the passive voice in L1 and L2 academic texts". Language Teaching Research 8 (1): 5-29.

Hung, H. T. 2015. "Flipping the classroom for English language learners to foster active learning”. Computer Assisted Language Learning. 28 (1): 81-96. https:// doi.org/10.1080/09588221.2014.967701.

Izquierdo, J. 2014. "Multimedia Instruction in Foreign Language Classrooms: Effects on the Acquisition of the French Perfective and Imperfective Distinction". The Canadian Modern Language Review/La Revue canadienne des langues vivantes 70 (2): 188-219. http://doi.org/10.3138/cmlr.1697.

Izquierdo, J., Simard, D. and M. G. Garza Pulido. 2015. "Multimedia Instruction \& Language Learning Attitudes: A Study with University Students". Revista Electrónica de Investigación Educativa 17 (2): 101-115.

Kawauchi, D. 2005. "Proficiency differences in Call Based Vocabulary Learning: The Effectiveness of Using 'PowerWords". FLEAT 5: 55-65.

Kiliçkaya, F. 2015. "Computer-based grammar instruction in an EFL context: improving the effectiveness of teaching adverbial clauses". Computer Assisted Language Learning 28 (4): 325-340. http://doi.org/10.1080/09588221.2013.8 18563.

Klein, W. 2008. "Time in Language, Language in Time”. Language Learning 58 (Supplement 1): 1-12. 
Macedo-Rouet, M., Ney, M., Charles, S. and G. Lallich-Boidin. 2009. "Students' performance and satisfaction with Web vs. paper-based practice quizzes and lecture notes". Computers and Education 53 (2): 375-384.

Martínez-Adrián, M. and M. J. Gutiérrez-Mangado. 2015. "Is CLIL instruction beneficial both in terms of general proficiency and specific areas of grammar?". Journal of Immersion and Content-Based Language Education 3 (1): 51-76.

Martínez Pardo, A. 2014. Computer-Based vs. Textbook-Based Grammar Instruction: Effectiveness and Students' Perceptions. Unpublished Master's Thesis. Public University of Navarra: Spain.

Mohammadi, E. and S. S. Mirdehghan. 2014. "A CMC Approach to teaching phrasalverbs to Iranian EFL senior high school students: The case of blended learning". Procedia - Social and Behavioral Sciences 98: 1174-1178.

Nagata, N. 1998a. "Input versus output practice in educational software for second language acquisition”. Language Learning and Technology 1: 23-40.

Nagata, N. 1998b. "The relative effectiveness of production and comprehension practice in second language acquisition". Computer Assisted Language Learning 11: $153-177$.

Nutta, J. 1998. "Computer-based grammar instruction as effective as teacher-directed grammar instruction for teaching L2 structures?" CALICO Journal 16 (1): 49-62.

Penning de Vries, B., Cucchiarini, C, Bodnar, S., Strik, H. and R. van Hout. 2015. "Spoken grammar practice and feedback in an ASR-based CALL system" Computer Assisted Language Learning 28 (6): 550-576. http://doi.org/10.1080/ 09588221.2014 .889713$.

Sagarra, N. and G. C. Zapata. 2008. "Blending classroom instruction with online homework: A study of student perceptions of computer-assisted L2 learning". ReCALL 20 (02): 208-224. https://doi.org/10.1017/S0958344008000621.

Salaberry, R. 2000. L2 "Morphosyntactic Development in Text-Based ComputerMediated Communication”, Computer Assisted Language Learning 13 (1): 5-27. https://doi.org/10.1076/0958-8221(200002)13:1;1-K;FT005.

Soleimani, H. and A. Raeesi. 2015. "Hot Potatoes: The Merits and Demerits". Theory and Practice in Language Studies 5 (6): 1291-1295.

Stelea, S. and C. Girón García. 2017. "Computer-assisted instruction: 'JClic' as a new pedagogical tool for EFL learners". International Journal of Education and Development using Information and Communication Technology (IJEDICT) 13 (1): 4-31

Storch, N. 2013. Collaborative Writing in L2 classrooms. Bristol, UK: Multilingual Matters. 
Swain, L. O. and T. D. Swain. 2017. "Language learning under classroom conditions during the transition to hybrid instruction: A case study of student performance during the implementation of instructional technology". European Journal of Foreign Language Teaching 2 (3): 49-64. http://doi.org/10.5281/zenodo.1034563.

Torlakovic, E. and D. Deugo. 2004. "Application of a CALL system in the acquisition of adverbs in English". Computer Assisted Language Learning 17 (2): 203-235. http://doi.org/10.1080/0958822042000334244.

Villarreal, I. 2011. Tense and Agreement in the Non-Native English of BasqueSpanish Bilinguals: Content and Language Integrated Learners vs. English as a School Subject Learners. Unpublished Ph. D. thesis. Universidad del País Vasco: Spain.

Zhao, Y. 2003. "Recent developments in technology and language learning: a literature review and meta-analysis". CALICO Journal 21 (1): 7-27. 


\section{APPENDICES}

APPENDIX 1A: FIRST PAGE OF THE 15-PAGE C1-C2 TUTORIAL

\section{TTV zone}

\section{Tense The Verb}

\section{PRESENT TIME}

\section{PRESENT SIMPLE}

We use the present simple for:

1) Facts that are always true.

Example: Water freezes at 0 degrees Celsius.

2) Habits and states.

Examples: People normally have a siesta in the south of Spain.

I hate gore films.

3) Declarations/opinions and feelings.

Examples: People normally have a siesta in the south of Spain.

I hate gore films.

4) Instructions.

Example: First you mix the dough and then you leave it to cool, 


\section{PRESENT TIME}

There are two main ways of using a verb to refer to the present time: the Present Simple and the Present Continuous.

\section{PRESENT SIMPLE}

The Present Simple is the most common way of expressing present time.

The Present Simple has three major meanings:

1) The Present Simple is used when the speaker thinks of something as a fact which is always true or generally true.

Examples: The sun rises in the east.

Love makes the world go round

2) The Present Simple often indicates a state which exists now. It refers to a state with no definite start and finish time but true now.

Examples: Where does Mary live?

My dad works in Panama.

She looks like her mother.

3) The Present Simple can also refer to an action we repeat regularly, i.e. a habit or custom, often with frequency adverbs e.g. 'usually', 'always', 'never', 'sometimes', etc.

Examples: My children play handball three times a week.

I usually take the bus to work.

She never gives me presents. 
APPENDIX 2A: SAMPLE JCLOZE ACTIVITY (WITH ANSWERS PROVIDED HERE) FOR HOMEWORK PRACTICE LEVEL B1-B2

] JCloze: F:PIE 2013\HOT-POTATOES ACTIVTIES Jjumble Inés 2.jcl

L

\begin{tabular}{|c|c|c|c|c|}
\hline File Edit Insert Options He & & & & \\
\hline 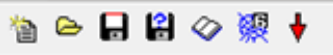 & 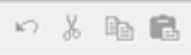 & 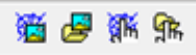 & 89 & ? \\
\hline
\end{tabular}

Title

|Tense the Verb: exercise 2

1. This tooth has been killing (kill) me lately! So I have made (make) an appointment with the dentist for Thursday.

2. When Nicola got off (get off) the bus it was raining (rain) heavily; she went (go) into a shop to buy an umbrella because she had left (leave) her old umbrella at home.

3. Lets go and see Anthony. We last saw (last/ see) him a long time ago.

4. This time next tomorrow I will be eating (eat) lunch on the plane!

5. Maria has been writing (write) her novel for the last five months without getting further than Chapter One.

6. Mikel, will you be using (you / use) the printer later today?

7. Have you finished (you/ finish) yet?

8. When I got up this morning the birds were singing (sing).

9. She retired (retire) from work early but she had worked (work) hard all her life.

10. As soon as she saw (see) him, she just laughed (laugh).

11. They will have delivered (deliver) the flowers by tomorrow.

12. I am seeing (see) the doctor next week. I have an appointment.

13. Paul hasn't been (be) to London since we went there together.

14. I was having (have) lunch at the café when I saw Peter in the street.

15. We went indoors because it was raining (rain). 
APPENDIX 2B: SAMPLE JCLOZE ACTIVITY (WITH ANSWERS PROVIDED HERE) FOR HOMEWORK PRACTICE LEVEL C1-C2

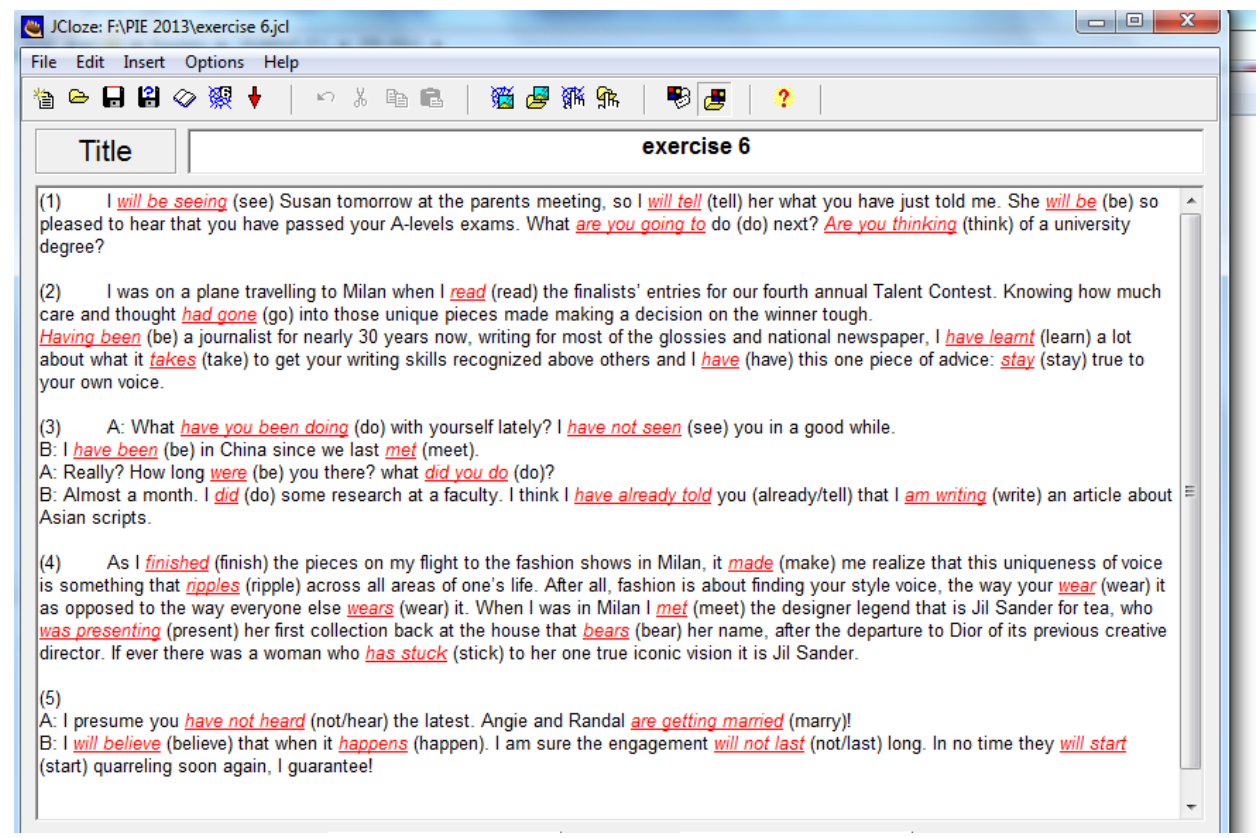




\section{PRE-TEST}

(WITH ANSWERS)

1. He has never uttered (never/uttered) the words 'I'm sorry' in his whole life.

2. Where did you get (you/get) those boots from? They are so funky!

3. In less than twenty-four hours I will be relaxing (relax) on my sail boat in Menorca, Spain.

4. Mark: You have been (be) on the phone for ages. Have you not nearly finished /Are you nearly finished (you/not/nearly/finish)?

Jane: I haven't got through (not/get through) yet. I have been trying/'m trying (try) to get our New York office but the line has been (be) engaged all morning.

5. What are you doing (you/do) this Sunday evening? Fancy a movie?

6. Get a move on or we will miss (miss) the bus!

7. Can you send the results as soon as you have (have) them, please?

8. He would always do/always used to do/was always doing (always/do) something like that when we were kids.

9. Sir George and Lady Bannister will have been married (marry) for 25 years next November. They are celebrating /are going to celebrate (celebrate) their wedding anniversary with a dinner party at Handcliff Castle. I'm sure lots of good food will be served (serve). Tom and Andy have been invited and are going (go). Keenan was invited too. but she cannot make it as she will have left 